\title{
Cryptosporidium Infection and Correlation with CD4+ T-cell count among Human Immunodeficiency Virus Seropositive Patients within Kaduna Metropolis, Nigeria
}

\author{
Aminu M. ${ }^{*}$, Ndaks C.M. and Ella E.E.
}

\author{
Department of Microbiology, Faculty of Science, Ahmadu Bello University, Zaria-Nigeria
}

\begin{abstract}
Cryptosporidiosis being an opportunistic infection is becoming more prevalent in Human Immunodeficiency Virus (HIV) seropositive patients. This study was carried out to determine the prevalence of Cryptosporidium infection and the correlation with CD4+ T-cell count among HIV seropositive patients within Kaduna Metropolis, Nigeria. Stool samples were collected from 300 HIV seropositive patients between October 2011 and January 2012, and examined for oocysts and antigen of Cryptosporidium by microscopy and ELISA methods. Microscopy was used as the Gold standard and its sensitivity was compared with that of ELISA. The blood samples were also analyzed for CD4+ T-cell count by flow cytometry. Prevalence of $15 \%$ (45/300) was obtained by microscopy. Sensitivity of microscopy when compared to ELISA was found to be $24.9 \%$. Cryptosporidium infection was associated with those who defecate in open layouts (50\%: $3 / 6)$ and those who drank river water without boiling (50\%: 1/2). There was a significant association between Cryptosporidium infection and diarrhoea $\left(\chi^{2}=104.669, \mathrm{df}=1, \mathrm{p}=0.000\right)$ and also the duration of diarrhoea $\left(\chi^{2}=117.073\right.$, $\mathrm{df}=4, \mathrm{p}=0.000)$. The oocysts were detected more frequently in males $(19.8 \%: 18 / 91)$ than female patients $(12.9 \%: 27 / 209)$ and patients between age group 16-25 years were most affected (25.7\%: 9/35). Cryptosporidium infection was not associated with occupation, marital status, sex, age, education, animal contact, overseas travel and swimming ( $>0.05)$ in this study. There was a decrease in prevalence with longer duration of being on HAART. The mean CD4+ T-cell count of patients was $409.86 \pm 14.1$ while the median was 382 . There was a strong association between cryptosporidiosis and CD4+ T-cell count $\left(\chi^{2}=58.478, \mathrm{df}=10, \mathrm{p}=0.000\right)$ with the highest prevalence recorded among patients with CD4+ T-cell count $<200 \mathrm{cell} / \mu \mathrm{l}$. This indicates that there is low opportunity for this parasite to get established as the patients CD4+ T-cell count increases and confirms the organism opportunistic nature.
\end{abstract}

Keywords: CD4+ T-cell count, Cryptosporidium, ELISA, HIV patients, Kaduna, Microscopy, Nigeria, Prevalence.

\section{INTRODUCTION}

Human immunodeficiency virus (HIV) infection is a global health emergency. According to World Health Organization progress report of 2010, 33.3 million people are living with HIV worldwide, 2.6 million people were infected in 2009 and 1.8 million people died of acquired immune-deficiency syndrome (AIDS) in that same year. The condition progressively reduces the effectiveness of the immune system and leaves the individual susceptible to opportunistic infections and tumors. Diarrhoea is a common clinical manifestation of HIV regardless of whether or not patients have AIDS [1]. The etiology of such diarrhoea could either be parasitic, bacterial, fungal, enteroviral or HIV itself [2]. Several species of intestinal parasites have been associated with diarrhoea which occurs in up to $80 \%$ of persons with HIV infection [3]. The commonly reported parasites include Cryptosporidium parvum, Isospora belli, Microsporidium spp, Giardia lamblia, Entamoeba

*Address correspondence to this author at the Department of Microbiology, Faculty of Science, Ahmadu Bello University, Zaria-Nigeria;

Tel: +234 8033287031 ;

E-mail: maryamaminu@yahoo.com histolytica and Cyclospora spp. [4]. Cryptosporidium, Cyclospora and Isospora have been shown to complicate HIV infection by causing chronic diarrhoea which facilitates progression to AIDS [5-10].

Cryptosporidium parvum, a coccidian parasite belonging to the genus Cryptosporidium and phylum Apicomplexa [11] causes cryptosporidiosis, an infection which is generally self-limiting except in the immuno-suppressed, where infection may be prolonged and fatal [12]. There are no reproducible reliable palliative or curative therapies for this infection and HIV infected persons are not educated and counseled about the modes of transmission and prevention. The Cryptosporidium parasite is transmitted by environmentally hardy microscopic cyst (oocyst) which excyst in the small intestine once ingested and results in infection of intestinal epithelial tissue. A major problem of public health concern is the fact that the oocysts are only 4 to $6 \mu \mathrm{m}$ in diameter, much too small to be easily removed by sand filters used to purify drinking water [13]. In addition the oocyst may remain viable for 3 to 6 months in moist environment and is extremely resistant to disinfectants such as chlorine.

The prevalence of coccidian parasitic infection is high and widely distributed in sub-Saharan Africa, where majority 
of HIV cases are located [14]. Some studies conducted in Nigeria have shown that the prevalence of Cryptosporidium infection is high among HIV seropositive patients. Prevalence of $16.83 \%$ [15], 25\% [16] and 22.2\% [17] have been reported. The prevalence rate is usually under estimated because conventional diagnostic techniques do not efficiently detect the parasite, so it is not routinely tested. Therefore, there have been inadequate studies addressing this problem in Nigeria, hence the need to document the prevalence of Cryptosporidium infection among HIV seropositive patients and its correlation to CD4+ T-cell count.

\section{MATERIALS AND METHODS}

\section{Study Area and Population}

The study was conducted in Kaduna Metropolis, Kaduna State, Nigeria, between October 2011 and January 2012. Kaduna Metropolis covers an area of $3,080 \mathrm{~km}^{2}$ and is a major hub for the surrounding agricultural areas and an industrial center of Northern Nigeria. The population of Kaduna Metropolis is about 760,084 according to the 2006 Census. It has a characteristic southern Guinea Savannah climatic condition; where the two seasons, dry and wet, match the vegetation type typical of the zone.

The study was carried out among HIV seropositive patients attending Antiretroviral (ARV) Clinics in three health care facilities within the Metropolis. These facilities included Barau Dikko Specialist Hospital located in Kaduna North, Gwamna Awan General Hospital located in Kaduna South and Yusuf Dantsoho General Hospitals located in Kaduna West. The study population included male and female patients aged between 16 and 65 years from all works of life attending the selected clinics.

\section{Inclusion and Exclusion Criteria}

The inclusion criteria were, consenting, being HIV positive and attending the ARV clinics within the study period; while the exclusion criteria were being HIV negative and not consenting.

\section{Ethical Approval and Consent}

Approval to carry out the research was given by the Hospital Ethical Committee of Kaduna State Ministry of Health. The consent of individuals recruited for the study was obtained and they were educated on the purpose and benefits of the study.

\section{Study Design}

The study was hospital based employing 300 consenting patients regardless of whether they were on highly active antiretroviral therapy (HAART) or not. Samples were collected consecutively from every other HIV positive patient who came to the clinic during the study period. From each of the selected hospital, 100 blood and 100 stool samples were collected.

\section{Data Collection and Sample Size Determination}

A semi-structured questionnaire was designed to obtain data on the patients' socio-demography, clinical information, and some possible risk factors that might be associated with cryptosporidiosis.

The sample size used for the study was determined using the equation below as described by Naing et al. [18]:

$\frac{n=z^{2} p(1-p)}{d^{2}}$

Where $\mathrm{n}=$ sample size, $\mathrm{z}=$ statistics for a level of $95 \%$ confidence interval $=1.96, \mathrm{p}=$ prevalence rate of Cryptosporidium infection among HIV seropositive patient $=$ $22.2 \%$ [17] and $\mathrm{d}=$ precision (allowable error) $=5 \%=0.05$.

The calculated sample size was 265 , which was the minimum number of samples to be used for the study. Hence, 300 stool and 300 blood samples were collected and used for the study

\section{Sample Collection and Processing}

Prior to sample collection, a questionnaire was issued to each consenting participant after counseling, completed, and returned. Five milliliters $(5 \mathrm{ml})$ of blood was collected aseptically from each of the 300 patients by a laboratory technician into a vacutainer containing EDTA, placed on a roller mixer and used for $\mathrm{CD}^{+} \mathrm{T}$-cell enumeration. Also, 300 stool samples were collected into clean wide-mouthed stool specimen containers and used for detecting Cryptosporidium by microscopy and ELISA. One hundred blood and 100 stool samples were collected from each of the hospital. The blood samples for CD4+ T-cell count and stool microscopy were processed immediately after collection while stool samples for ELISA were transported to the Department of Microbiology, Ahmadu Bello University Zaria and stored at $-20^{\circ} \mathrm{C}$ until analyzed.

\section{Sample Analysis}

\section{Microscopic analysis of stool samples by formal ether concentration and modified Ziehl-Neelsen (Zn) method}

The method described by Chesbrough [19] was used. About one gram of stool was emulsified in about $4 \mathrm{ml}$ of $10 \%$ formol water in a tube and $3 \mathrm{ml}$ of $10 \% \mathrm{~V} / \mathrm{V}$ formol water was added. The tube was capped and the mixture was mixed properly by shaking. The emulsified stool was sieved into a beaker. The supernatant was transferred into a centrifuge tube and $3 \mathrm{ml}$ of diethyl ether was added. The tube was stoppard, mixed for 1 minute and centrifuged immediately at $1000 \mathrm{rpm}$ for 1 minute. A Pasteur pipette was used to carefully remove the entire column of fluid below the faecal debris and ether; this was transferred to another centrifuge tube. Formol water was added to make the volume up to $10 \mathrm{ml}$; this was then centrifuge at $3000 \mathrm{rpm}$ for 5 minutes. The supernatant was removed and the bottom of the tube tapped to re-suspend and mix the sediment.

A smear from the sediments was prepared on a slide. The smear was air dried, fixed with methanol for 2-3 minutes and stained with unheated carbol-fuchsin for 15 minutes and then 
Table 1. Prevalence of Cryptosporidium infection among HIV seropositive patients attending some selected Hospitals within Kaduna Metropolis, Nigeria.

\begin{tabular}{|c|c|c|c|c|c|}
\hline \multirow[b]{2}{*}{ Hospital } & \multicolumn{2}{|c|}{ *ELISA } & \multicolumn{2}{|c|}{ **Microscopy } & \multirow[b]{2}{*}{ Total } \\
\hline & Positive (\%) & Negative (\%) & Positive (\%) & Negative (\%) & \\
\hline Barau Dikko & $71(71.0)$ & $29(29.0)$ & $16(16.0)$ & $84(84.0)$ & 100 \\
\hline Yusuf Dantsoho & $72(72.0)$ & $28(28.0)$ & $22(22.0)$ & $78(78.0)$ & 100 \\
\hline Gwamna Awan & $34(34.0)$ & $66(66.0)$ & $7(7.0)$ & $93(93.0)$ & 100 \\
\hline Total & $177(59.0)$ & $123(41.0)$ & $45(15.0)$ & $255(85.0)$ & 300 \\
\hline
\end{tabular}

Key: $*=$ ELISA $* *=$ Microscopy

$*\left(\chi^{2}=38.7764, \mathrm{df}=2, \mathrm{p}=0.000\right), * *\left(\chi^{2}=8.941, \mathrm{df}=2, \mathrm{p}=0.012\right)$.

washed off with water. The smear was decolorized with $1 \%$ acid alcohol for 10-15 seconds, washed off with water, counterstained with $0.5 \%$ malachite green for 30 seconds, washed off with water and placed on a draining rack to dry. Stained smear were observed for oocysts with an Olympus microscope. The $\mathrm{x} 10$ objective was used to detect the oocyst and the $\mathrm{x} 100$ objective was used to identify them. The diameter of the oocyst (4-6 um) was measured using a microscope equipped with an ocular micrometer and calibrated against a stage micrometer, which has uniformly spaced lines of known distance etched on it.

\section{Cryptosporidium Antigen Detection by ELISA}

All stool samples were tested for the presence of Cryptosporidium antigen by a commercially available ELISA kit (Cryptosporidium Faecal kit, Diagnostic Automation, Inc. USA). The assay was carried out according to the manufacturer's instructions. A sandwich ELISA was used to capture Cryptosporidium antigen present in the stool samples. Reactions were read using an ELISA plate reader (GF-M3000 B. Brian Scientific and Instrument Company England) at $450 \mathrm{~nm}$. Absorbance value of 0.15 Optical Density (OD) units and above indicated that the sample contained Cryptosporidium antigen (positive) while an absorbance value less than 0.15 OD units indicated that the sample did not contain a detectable level of Cryptosporidium antigen (negative).

\section{CD4+ T-cell Count}

Blood sample were placed on the roller mixer for at least 15 minutes for proper mixing and $20 \mu \mathrm{l}$ of $\mathrm{CD}_{4}{ }^{+}$easy count$\mathrm{CD}_{4}{ }^{+}$monoclonal antibody was added to a partec test tube. To this was added $20 \mu \mathrm{l}$ of blood sample and incubated for 15 minutes in the dark at room temperature $\left(25-30^{\circ} \mathrm{C}\right)$ mixing at intervals. After wards, $800 \mu \mathrm{l}$ of $\mathrm{CD}_{4}{ }^{+}$easy count-No lyse buffer was added to the tube and shaken gently. Blood samples were analyzed on a Cyflowpartec device (071040020 Partec GmbH Germany).

\section{Data Analysis}

The results obtained were analyzed using the SPSS version 17.00 statistical software. Results were reduced to percentages and presented in tables and figures. Chi-square test was used to test for significant association and p-value $<0.05$ was considered significant.

\section{RESULT}

Cryptosporidium was detected in the stools of $45(15.0 \%)$ and $177(59.0 \%)$ of the patients by microscopy and ELISA respectively. There was a significant difference in the prevalence of Cryptosporidium obtained among the selected hospitals by ELISA $\left(\chi^{2}=38.7764, \mathrm{df}=2, \mathrm{p}=0.000\right)$ and by microscopy $\left(\chi^{2}=8.941, \mathrm{df}=2, \mathrm{p}=0.012\right)$. The highest prevalence was recorded amongst patients attending Yusuf Dantsoho Hospital for ELISA (72.0\%: 72/100) and for microscopy (22.0\%: 22/100); while the lowest was recorded in Gwamna Awan Hospital for ELISA (34.0\%: 34/100) and for microscopy (7.0\%: 7/100) (Table 1).

The results of the socio-demographic factors of the patients are presented in Table 2. Patients in age group 16-25 years had the highest prevalence of Cryptosporidium (25.7\%: 9/35) while those in age group 36-45 years had the lowest $(10.4: 10 / 96)\left(\chi^{2}=4.975, \mathrm{df}=4, \mathrm{p}=0.290\right)$. Of the 45 patients from whom Cryptosporidium oocysts were detected, $18(19.8 \%)$ were male and $27(12.9 \%)$ were female. Rate of infection was higher in male than female patients $\left(\chi^{2}=2.341, \mathrm{df}=1, \mathrm{p}=0.126\right)$. Even though the prevalence of Cryptosporidium varied amongst the patients according to marital status, educational status and occupation of patients, these factors were not significantly associated with the infection in this study ( $\mathrm{p}>0.05)$.

Analysis of the results according to possible risk factors that might be associated with Cryptosporidium showed an association between Cryptosporidium infection and water source $\left(\chi^{2}=9.614, \mathrm{df}=4, \mathrm{p}=0.047\right)$. Although only two patients indicated they drank water from the river, Cryptosporidium was detected in the stool of all of them by ELISA and in one of them by microscopy but was not detected in patients who drank water from other sources such as packaged and bottled water (Table 3). Prevalence of Cryptosporidium was higher among patients who did not boil their drinking water (16.0\%: 42/262) compared to those who did (7.9\%: 3/38) $\left(\chi^{2}=1.723, \mathrm{df}=1, \mathrm{p}=0.189\right)$. Cryptosporidium oocysts were detected in the stools of three of the six patients who defecated in opened layouts while $10.6 \%(19 / 180)$ of those who used water cistern were excreting the oocysts $\left(\chi^{2}=10.948, \mathrm{df}=2, \mathrm{p}=0.004\right)$. 
Table 2. Distribution of Cryptosporidium infection by demographic factors among HIV seropositive patients within Kaduna Metropolis, Nigeria.

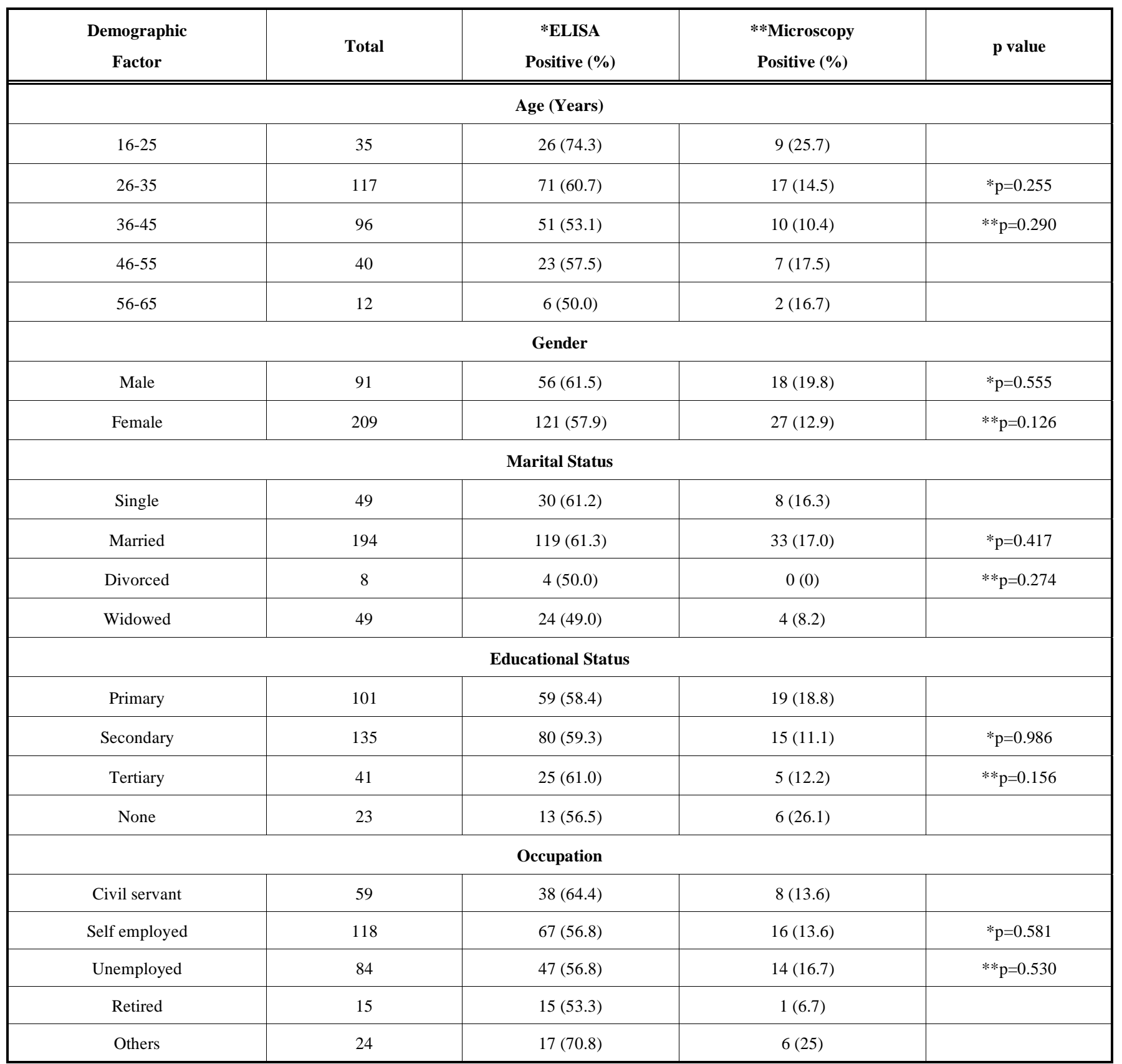

Key: $*$ ELISA, $* *=$ Microscopy

Table 3. Distribution of Cryptosporidium infection in relation to risk factors among HIV seropositive patients within Kaduna Metropolis, Nigeria.

\begin{tabular}{|c|c|c|c|c|}
\hline \multicolumn{2}{|c|}{ Risk Factor } & Total & *ELISA Positive (\%) & **Microscopy Positive (\%) \\
\hline \hline \multicolumn{3}{|c|}{ Source of Water } \\
\hline Tap & 202 & $119(58.90)$ & $25(12.4)$ \\
\hline Well & 93 & $56(60.2)$ & $19(20.4)$ \\
\hline Rivers & 2 & $2(100)$ & $1(50.0)$ \\
\hline Others & 3 & $0(0)$ & 0.217 \\
\hline
\end{tabular}


Table 3. contd...

\begin{tabular}{|c|c|c|c|c|}
\hline Risk Factor & Total & *ELISA Positive (\%) & **Microscopy Positive (\%) & p value \\
\hline \multicolumn{5}{|c|}{ Boiling of Water } \\
\hline Yes & 38 & $20(52.6)$ & $3(7.9)$ & $* \mathrm{p}=0.393$ \\
\hline No & 262 & $157(59.9)$ & $42(16.0)$ & $* * \mathrm{p}=0.189$ \\
\hline \multicolumn{5}{|c|}{ Type of Toilet } \\
\hline Water cistern & 180 & $97(53.9)$ & $19(10.6)$ & $* \mathrm{p}=0.061$ \\
\hline Pit latrine & 114 & $75(65.8)$ & $23(20.2)$ & $* * \mathrm{p}=0.004$ \\
\hline Open layout & 6 & $5(83.3)$ & $3(50.0)$ & \\
\hline \multicolumn{5}{|c|}{ Animal Contact } \\
\hline Yes & 44 & $27(61.4)$ & $10(22.7)$ & $* \mathrm{p}=0.730$ \\
\hline No & 256 & $150(58.6)$ & $35(13.7)$ & $* * \mathrm{p}=0.120$ \\
\hline \multicolumn{5}{|c|}{ Swimming } \\
\hline Yes & 12 & $5(41.7)$ & $2(16.7)$ & $* \mathrm{p}=0.213$ \\
\hline No & 288 & $172(59.7)$ & $43(14.9)$ & $* * \mathrm{p}=0.869$ \\
\hline \multicolumn{5}{|c|}{ Overseas Travel } \\
\hline Yes & 16 & $9(56.3)$ & $2(12.5)$ & $* \mathrm{p}=0.818$ \\
\hline No & 284 & $168(59.2)$ & $43(15.1)$ & $* * \mathrm{p}=0.773$ \\
\hline
\end{tabular}

Key: * ELISA, ** = Microscopy

Table 4. Distribution of Cryptosporidium infection in relation to clinical symptoms among HIV seropositive patients within Kaduna Metropolis, Nigeria.

\begin{tabular}{|c|c|c|c|c|}
\hline Symptom & Total & *ELISA Positive (\%) & **Microscopy Positive (\%) & p value \\
\hline \multicolumn{5}{|c|}{ Diarrhoea } \\
\hline Yes & 59 & $45(76.3)$ & $34(57.6)$ & $* \mathrm{p}=0.002$ \\
\hline No & 241 & $132(54.8)$ & $11(4.6)$ & $* \mathrm{p}=0.000$ \\
\hline \multicolumn{5}{|c|}{ Diarrhoea Duration (Days) } \\
\hline No diarrhoea & 241 & $132(54.8)$ & $11(4.6)$ & \\
\hline $1-2$ & 31 & $24(77.4)$ & $15(48.4)$ & $* \mathrm{p}=0.05$ \\
\hline $3-5$ & 20 & $17(85.0)$ & $15(75.0)$ & $* * \mathrm{p}=0.000$ \\
\hline 7 & 6 & $4(66.7)$ & $4(66.7)$ & \\
\hline $14-28$ & 2 & $0(0)$ & $0(0)$ & \\
\hline \multicolumn{5}{|c|}{ Others } \\
\hline No symptom & 187 & $107(57.2)$ & $15(8.0)$ & \\
\hline Fever & 43 & $30(69.8)$ & $11(25.6)$ & $* \mathrm{p}=0.459$ \\
\hline Abdominal cramp & 40 & $22(55.0)$ & $11(27.5)$ & $* * \mathrm{p}=0.000$ \\
\hline Anorexia & 5 & $4(80.0)$ & $3(60.0)$ & \\
\hline
\end{tabular}


Table 4. contd...

\begin{tabular}{|c|c|c|c|c|}
\hline Symptom & Total & *ELISA Positive (\%) & **Microscopy Positive (\%) & p value \\
\hline \hline Nausea & 12 & $8(66.7)$ & $4(33.3)$ & $1(7.7)$ \\
\hline Malaise & 13 & $6(46.2)$ & \\
\hline
\end{tabular}

Key: $*=$ ELISA, $* *=$ Microscopy

Table 5. Prevalence of Cryptosporidium infection among HIV seropositive patients within Kaduna Metropolis by their HAART status.

\begin{tabular}{|c|c|c|c|c|c|}
\hline \multirow{2}{*}{ HAART } & \multicolumn{2}{|c|}{ *ELISA } & \multicolumn{2}{c|}{ **Microscopy } & \multirow{2}{*}{ Total } \\
\cline { 2 - 5 } & Positive (\%) & Negative (\%) & Positive (\%) & Negative (\%) & 207 \\
\hline \hline Yes & $122(58.9)$ & $85(41.1)$ & $37(17.9)$ & $85(91.4)$ & 93 \\
\hline No & $55(59.1)$ & $38(40.9)$ & $8(8.6)$ & $255(85.0)$ & 300 \\
\hline Total & $177(59.0)$ & $123(41.0)$ & $45(15.0)$ & \\
\hline
\end{tabular}

Key: $*=$ ELISA $* *=$ Microscopy

$*\left(\chi^{2}=001, \mathrm{df}=1, \mathrm{p}=0.974\right) * *\left(\chi^{2}=4.327, \mathrm{df}=1, \mathrm{p}=0.038\right)$

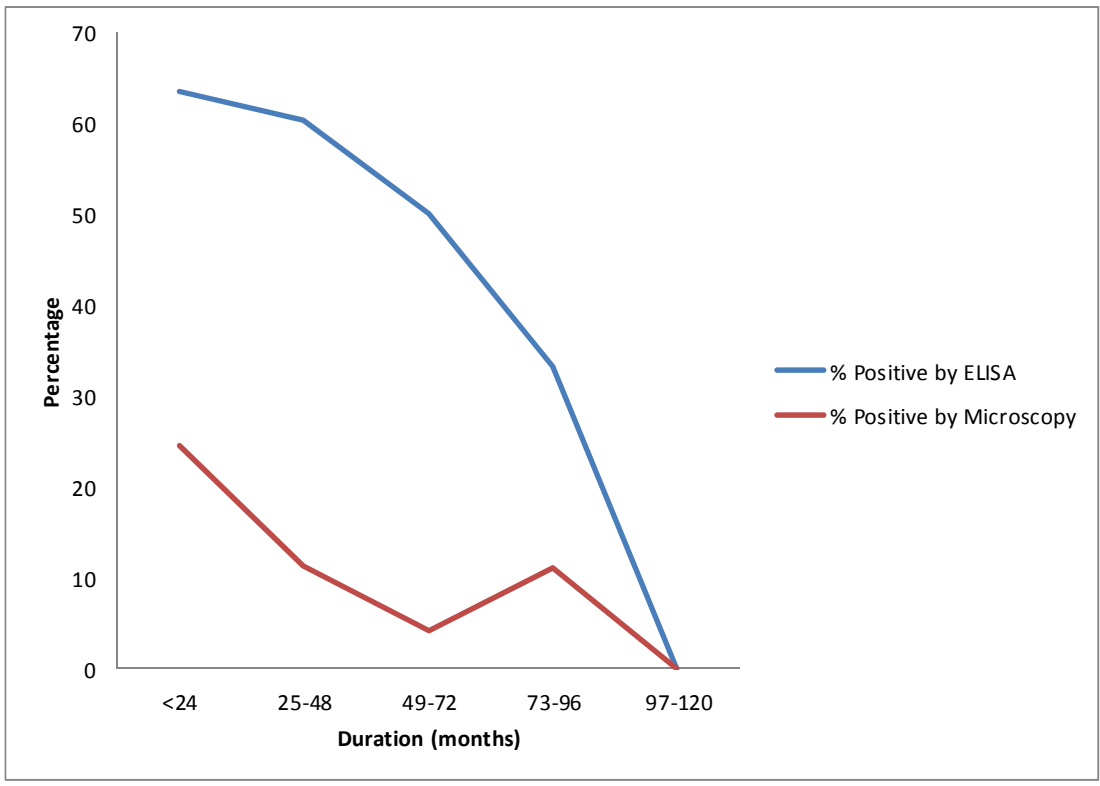

Fig. (1). Prevalence of Cryptosporidium infection among HIV seropositive patients within Kaduna Metropolis in relation to duration on HAART.

Cryptosporidium infection was detected with a higher prevalence $(22.7 \%$ : 10/44) among animal owners than nonanimal owners $(13.7 \%$ : $35 / 256)\left(\chi^{2}=2.415, \mathrm{df}=1, \mathrm{p}=\right.$ $0.120)$, among swimmers $(16.7 \%: 2 / 12)$ than non-swimmers (14.9\%: 43/288) $\left(\chi^{2}=0.27, \mathrm{df}=1, \mathrm{p}=0.869\right)$, and among those that had never travelled overseas $(15.1 \%: 43 / 284)$ than those who had $(12.5 \%$ : $2 / 16)\left(\chi^{2}=0.083, \mathrm{df}=1 \mathrm{p}=0.773\right)$.

The clinical symptoms presented by the patients were analyzed in relation to Cryptosporidium infection (Table 4). Cryptosporidium infection was highly associated with diarrhoea $\left(\chi^{2}=104.669\right.$, df $\left.=1, p=0.000\right)$ and its duration $\left(\chi^{2}\right.$ $=117.073, \mathrm{df}=4, \mathrm{p}=0.000)$. Infection was highest among patients with diarrhoea duration between 3-5 days $(75.0 \%$ : 15/20) and was not detected in those with diarrhoea that had lasted for 2-4 weeks. Other symptoms associated with
Cryptosporidium were fever, anorexia, nausea malaise and abdominal cramps. There was a significant association between Cryptosporidium infection and these symptoms $(\mathrm{p}<0.05)$.

Two hundred and seven of the patients enrolled in the study were on HAART. There was a significant association $\left(\chi^{2}=4.327, \mathrm{df}=1, \mathrm{p}=0.038\right)$ between Cryptosporidium infection and patients on HAART. Patients on HAART had higher prevalence $(17.9 \%$ : 37/207) compared to those that were not (8.6\%: 8/93) (Table 5). Analysis of the result based on the duration on HAART showed that HIV patients who were on drugs for less than 24 months, had the highest prevalence of Cryptosporidium infection (24.6\%: 29/118) and the parasite was not detected in those on drugs for more than 97-120 months $\left(\chi^{2}=10.167, \mathrm{df}=4, \mathrm{p}=0.001\right)$ (Fig. 1). 
Table 6. Prevalence of Cryptosporidium infection among HIV seropositive patients in relation to CD4+ T-cell count.

\begin{tabular}{|c|c|c|c|c|c|}
\hline \multirow{2}{*}{$\frac{\text { CD4+ }}{\text { T-cell count }}$} & \multicolumn{2}{|c|}{ *ELISA } & \multicolumn{2}{|c|}{ **Microscopy } & \multirow{2}{*}{ Total } \\
\hline & Positive (\%) & Negative (\%) & Positive (\%) & Negative (\%) & \\
\hline$<200$ & $38(67.9)$ & $18(32.1)$ & 25 (44.6) & $31(55.4)$ & $56(18.67)$ \\
\hline $201-350$ & $41(61.1)$ & $26(38.9)$ & $16(23.9)$ & $51(76.1)$ & $67(22.33)$ \\
\hline $351-500$ & $49(53.8)$ & $42(46.2)$ & $3(3.3)$ & $88(96.7)$ & $91(33.33)$ \\
\hline $501-1000$ & $45(50.6)$ & $44(49.4)$ & $1(1.1)$ & $88(98.9)$ & 89 (29.67) \\
\hline$>1000$ & $4(57.1)$ & $3(42.9)$ & $0(0.0)$ & $7(100)$ & $7(23.33)$ \\
\hline Total & 177 (59.0) & $123(41.0)$ & $45(15.0)$ & $255(85.0)$ & $300(100)$ \\
\hline
\end{tabular}

Key: $*=$ ELISA $* *=$ Microscopy

$*\left(\chi^{2}=9.754, \mathrm{df}=4, \mathrm{p}=0.002\right), * *\left(\chi^{2}=24.888, \mathrm{df}=4, \mathrm{p}=0.000\right)$.

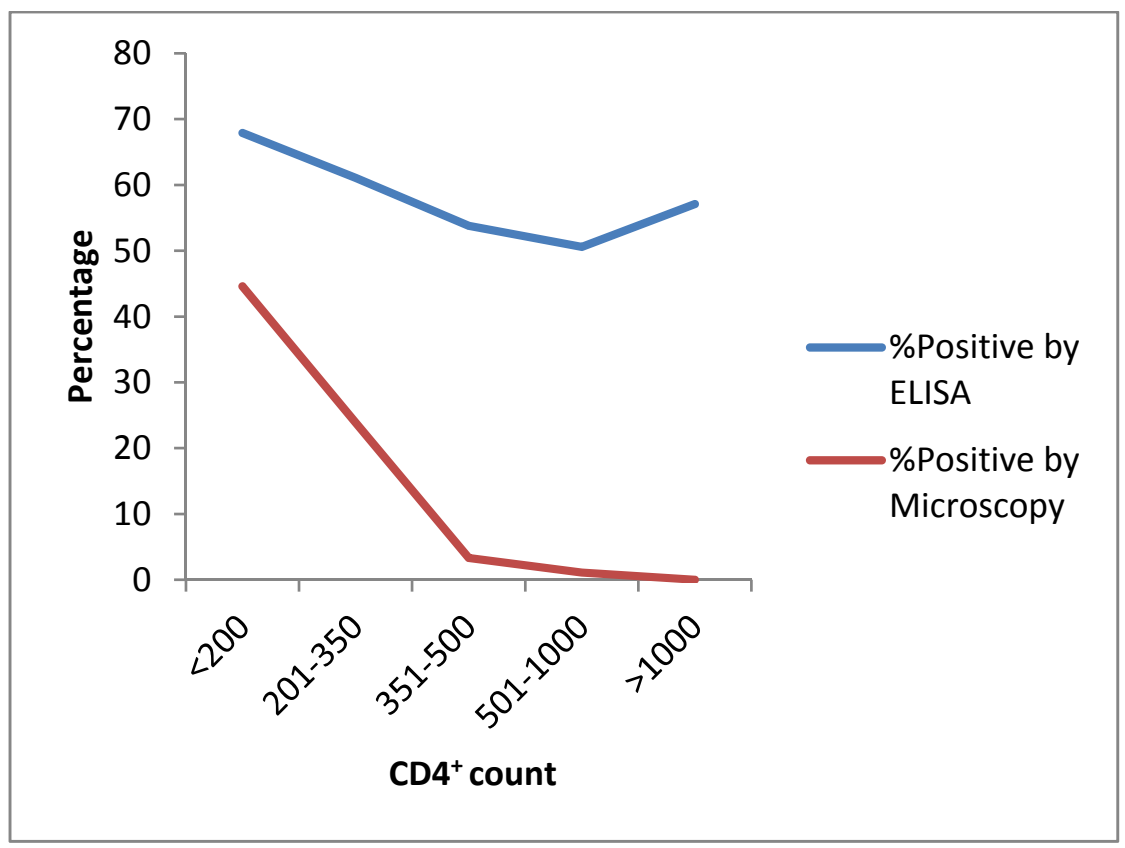

Fig. (2). Prevalence of Cryptosporidium infection among HIV seropositive patients in relation to CD4+ T-cell count.

There was a significant association $\left(\chi^{2}=24.888, \mathrm{df}=9, \mathrm{p}=\right.$ 0.000 ) between Cryptosporidium infection and CD4+ T-cell count. The mean CD4+ T-cell count was 409.86 while the median was 382. Patients with CD4+ T-cell count between101-200 had the highest prevalence by ELISA (75.9\%: 22/29) and microscopy (51.7\%: 15/29) while patients with CD4+ T-cell count between 901-1000 had the lowest prevalence by ELISA (0.6\%) and those with CD4+ Tcell count $>1000$ were not infected with Cryptosporidium (Table 6). There was a decrease in infection as CD4+ T-cell count increase by microscopy method (Fig. 2).

The sensitivity of microscopy was determined using ELISA as a standard. Out of the 45 patients that were positive by microscopy, 44 (True positive) were also positive by ELISA while 1 (False positive) was negative by ELISA. Sensitivity of microscopy was $24.9 \%$ and specificity was 91.2\% (Table 7).

\section{DISCUSSION}

A prevalence of $15 \%$ was obtained for Cryptosporidium among HIV seropositive patient in Kaduna State during October 2011 to January 2012. The same prevalence of $15 \%$ was reported in a study carried out in Venezuela [20] while an earlier study in Nigeria reported a prevalence of $18.7 \%$ among HIV patients with diarrhoea in Lagos [21]. In contrast, Nwokediuko et al. [22] and Oyerinde et al. [23] did not detect Cryptosporidium oocyst in their studies carried out among HIV patients in Enugu and Lagos respectively. The reasons for these variations may be related to the fact that infections tend to vary from one locality to another and from one country to another depending on the level of associated risk factors.

The results obtained by using the two methods varied. A higher prevalence of Cryptosporidium was obtained by ELISA $(59 \%)$ than by microscopy $(15 \%)$ indicating that 
Table 7. Sensitivity and specificity of microscopy using ELISA test as a standard.

\begin{tabular}{|c|c|c|c|}
\hline \multirow{2}{*}{ Microscopy } & \multicolumn{2}{|c|}{ *ELISA } & \multirow{2}{*}{ Total } \\
\cline { 2 - 4 } & Positive (\%) & Negative (\%) & 45 \\
\hline \hline Positive & 44 & 1 & 255 \\
\hline Negative & 133 & 122 & $\underline{123}$ \\
\hline
\end{tabular}

Sensitivity $=24.9 \%$

Specificity $=91.2 \%$

ELISA detected more Cryptosporidium infection than microscopy. This result is similar to that obtained by Elgun and Koltas [24] in Turkey, in which the prevalence obtained by ELISA $(24.03 \%)$ was higher than that of Microscopy $(5.19 \%)$. This may be due to microscopy being specific but less sensitive for the diagnosis of Cryptosporidium in faeces while ELISA has a higher sensitivity. Specificity of microscopy is due to the fact that the organism has to be intact before it can be seen while for ELISA it is the antigen that is being detected. Bialek et al. [25] also reported high sensitivity of ELISA as compared to microscopy.

Infection was detected most frequently amongst patients in age group 16-25 years; however there was no significant difference. This result is similar to the findings of Ibrahim et al. [15] in which a higher prevalence in age group 15-24 years was reported. This may be because incidence of HIV is also highest among individual between 15-35 years old [26]. Cryptosporidiosis was not significantly associated with gender although prevalence was higher in male than female as previously reported [17, 21, 27]. The result however contrasts that of Ibrahim et al. [15] where prevalence of intestinal parasitosis was more in female than male. Ikechukwu et al. [28] in a study on cryptosporidiosis in Imo state also reported that more female were infected than male. The finding in this study may be explained by the fact that more male are exposed on occupational grounds (rearing of animals) than female and female are more conscious of their personal hygiene than male.

In relation to marital status, educational status and occupation of patients, there was no association between Cryptosporidium infection and these socio-demographic factors. This result is similar to that obtained by Ibrahim et al. [15] but contrasts that of Akinbo et al. [17] and Assefa et al. [29]. This lack of association might be due to equal exposure of the patients to these factors.

Patients whose source of drinking water was tap water had the lowest rate of infection and those who drank from rivers had the highest. This agrees with the findings of Akinbo et al. [17] and Egberongbe et al. [30] and contrasts the report of Ikeh et al. [27]. A significant association existed between water source and Cryptosporidium infection. High rate of infection among patients who drank river water might be because cryptosporidiosis is largely water borne and activities such as bathing, defecating and washing take place in the river thereby contaminating the water. Patients who boiled water before drinking had lower prevalence of infection than those who did not and this may be due to the fact that boiling kills the oocysts of Cryptosporidium. This finding, however, did not agree with that of Hunter et al. [31], who found no association between cryptosporidiosis and drinking unboiled water.

Cryptosporidiosis was significantly association with the type of toilet used by patients in this study, with those who use open layout having the highest prevalence. This may be because flies in this environment can transmit Cryptosporidium oocysts to food which when consumed can be source of infection. In addition, there is usually no water in this environment and hand washing is not regularly practiced, therefore oocysts are transferred from hands to food or mouth. This finding is similar to that of Akinbo et al. [17] and Egberongbe et al. [30] who reported that, defeacating in nearby bushes resulted in significant increase in prevalence of cryptosporidiosis.

Patients who had farm animals had higher prevalence than those who did not $(\mathrm{P}>0.05)$. This agrees with the findings of Hunter et al. [31] who identified contact with cattle as a main risk factor of Cryptosporidium parvum infection. Morgan et al. [32] also identified higher frequency of animal contact in patients infected with zoonotic isolates from Kenya, Switzerland and United States. Higher prevalence in this category might be due to the fact that cryptosporidiosis is a zoonotic disease and can be contracted by contact with infected animals.

Prevalence of Cryptosporidium was higher in patients who swim compared to non swimmers $(\mathrm{P}>0.05)$ contrasting the findings of Hunter et al. [31]. The reason for this may be because chlorination is not enough to kill the oocysts of Cryptosporidium hence infection can be contracted from swimming pools. For overseas travel, prevalence was higher in patients who had never travelled overseas and the reason may be because the patients did not travel to endemic countries. This finding however agrees with that of Aragon et al. [33] but contrasts that of Hunter et al. [31].

Diarrhoea is a major symptom in cryptosporidiosis which was confirmed in this study as other similar studies have done [30, 34-36]. Reason for this may be because in HIV infection, diarrhoea is a major sign of progression to AIDS. Regarding the duration of diarrhoea, patients with diarrhoea that lasted between 3-5 days had higher prevalence of 
Cryptosporidium. This may be because cryptosporidiosis causes short self limiting watery diarrhoea which can resolve as immune status recovers and most patients enrolled in this study were on HAART which helps boost immune status. Patients on HAART had higher prevalence of Cryptosporidium than those not on HAART and the infection was highest in patients who were <24 months on HAART $(\mathrm{P}>0.05)$. There was decrease in prevalence with increase in period of being on HAART. Cryptosporidium oocyst was not detected in patients who had been on HAART for 97-120 months. This suggests that HAART reduces the prevalence of Cryptosporidium infection by boasting immunity. The present study found a higher prevalence of cryptosporidiosis among patients who had anorexia, while those with malaise had the lowest.

There was a significant association between Cryptosporidium infection and $\mathrm{CD} 4^{+} \mathrm{T}$-cell count. Prevalence was highest in patients with $\mathrm{CD}^{+} \mathrm{T}$-cell count $<200 \mathrm{cell} / \mu \mathrm{l}$. This finding is similar to that of Assefa et al. [29] and Gupta et al. [36] that showed that, the rate of parasitic infection decreases with increase in $\mathrm{CD} 4^{+} \mathrm{T}$-cell count. This indicates that there is low opportunity for this parasite to get established as the patients CD4 ${ }^{+} \mathrm{T}$-cell count increases.

\section{CONCLUSION}

The study showed a high prevalence of Cryptosporidium infection among HIV seropositive patients within Kaduna Metropolis. The ELISA technique used in the study was more sensitive than microscopy in detecting the parasite. Source of water and type of toilet were associated with Cryptosporidium infection in this study; an information useful in the prevention and control of cryptosporidiosis. Patients with high $\mathrm{CD}^{+} \mathrm{T}$-cell counts had low prevalence of Cryptosporidium, indicating that there is low opportunity for this parasite to get established as the patients $\mathrm{CD} 4{ }^{+} \mathrm{T}$-cell count increases, thus confirming the opportunistic nature of the infection.

\section{CONFLICT OF INTEREST}

The authors confirm that this article content has no conflict of interest.

\section{ACKNOWLEDEGEMENTS}

We acknowledge all the personnel in the hospitals and patients enrolled in the study for their cooperation.

\section{REFERENCES}

[1] Joshi M, Chowdhary AS, Dalal PJ, Maniar JK. Parasitic diarrhoea in patients with AIDS. Natl Med J India 2002; 15: 72-4.

[2] Framm SR, Soave R. Agents of diarrhoea. Med Clin North Am 1997; 81:427-47.

[3] Bowers M. Diarrhoea. Bull Exp Treat AIDS 1997; 6: 1-14.

[4] Arora DR, Arora B. AIDS-associated parasitic diarrhoea. Indian J Med Microbiol 2009; 27(3): 185-90.

[5] Hunter G, Bagshawe AF, Baboo KS, Luke R, Prociv P. Intestinal parasites in Zambian patients with AIDS. Trans R Soc Trop Med Hyg 1992; 86: 543-5.
Chintu C, Luo C, Baboo S, et al. Intestinal parasites in HIVseropositive Zambian children with diarrhoea. J Trop Pediatr 1995; 41: 149-52.

[7] Tarimo DS, Killewo JZ, Minjas JN, Msamanga GI. Prevalence of intestinal parasites in adult's patients with enteropathic AIDS in northeastern Tanzania. East Afr Med J 1996; 73: 397-9.

[8] Kumar SS, Ananthan S, Saravanan P. Role of coccidian parasites in causation of diarrhoea in HIV infected patients in Chennai. Indian $\mathrm{J}$ Med Res 2002; 116: 85-89.

[9] Mansfield LS, Gajadhar AA. Cyclospora cayetanensis, a food and water borne coccidian parasite. Vet Parasitol 2004; 126: 73-90.

[10] Pinlaor S, Mootsikapum P, Pinlaor P, Pipitgool V, Tuangnadee R. Detection of opportunistic and non-opportunistic intestinal parasites and liver flukes in HIV-positive and HIV-negative subjects. Southeast Asian J Trop Med Publ Hlth 2005; 36: 841-5.

[11] Martin K, Dana K, Bohamil S, Oley D. Cryptosporidium pig genotype II in immunocompetent man. J Infect Dis 2009; 15(6): 982-3.

[12] Kosek M, Akanlara A, Lima AAM, Guerrant RL. Cryptosporidiosis: an update. Lancet Infect Dis 2001; 1: 262-9.

[13] Willey JM, Sherwood LM, Woolverton CJ. Food-borne and water borne diseases and Human diseases, caused by viruses and prions, direct contact diseases In: Willey, JM, Sherwood LM, Woolverton CJ, (Eds.) Prescott's Microbiology. 8th Eds, New York. The McGraw Hill Companies. International Ed. 2011; pp. 897-93.

[14] Houpt ER, Bushen OY, Sam NE, Kohli A. Asymptomatic cryptosporidiosis infections among HIV infected patients in Tanzania. Afr Med J 2005; 31: 520-2.

[15] Ibrahim AK, Ikeh EI, Malo AO, Okeke EN, Damen JG. Intestinal parasitosis in human immunodeficiency virus (HIV) infected adults with chronic diarrhoea in Jos University Teaching Hospital, Jos, Nigeria. The Internet J Parasit Dis 2007; 2(1): 1559-4629.

[16] Aminu M and Yakubu YE. Prevalence of asymptomatic intestinal coccidian parasites infections among non-diarrhoeic HIV positive children in Nigeria. South Afr J Sci 2008; 104 (9/10): 348-50.

[17] Akinbo FO, Okaka CE, Omeregiel R. Prevalence of intestinal parasitic infections among HIV patients in Benin City, Nigeria. Libyan J Med 2010; 5: 5506.

[18] Naing L, Winn T, Rusli BN. Practical issues in calculating the sample size for prevalence studies. Arch Orofacial Scien 2006; 1: 9-14.

[19] Cheesbrough M. Parasitological test. In: District laboratory practice in tropical countries. Part 1. Cambridge University Press. 2005; pp $178-309$.

[20] Certad G, Arenas-Pinto A, Pocaterra G, Castro J, Bello A, Nunez, L. Cryptosporidiosis in HIV infected Venezuelan adult is strongly associated with acute or chronic diarrhoea. Am J Trop Med and Hyg 2005; 73(1): 54-7.

[21] Akunjobi CN, Ogunsola FT. Prevalence of Cryptosporidium species in patient with human immunodeficiency virus/acquired immunodeficiency syndrome presenting with diarrhoea in Lagos. Nig Q J Hosp Med 2005; 15: 119-22.

[22] Nwokediuko SC, Bojuwoye BJ, Onyenekwe B. Apparent rarity of cryptosporidiosis in human immunodeficiency virus (HIV) related diarrhoea in Enugu, Southeastern, Nigeria. Nig Postgrad Med J 2002; 9(2): 70-3.

[23] Oyerinde JP, Odugbemi T, Benson RI, Alonge AA, Roberts JI. Investigation of Cryptosporidium in relation to other intestinal parasites at the Lagos University Teaching Hospital, Lagos. West Afr J Med 1989; 8(4): 264-9.

[24] Elgon G, Koltas IS. Investigation of Cryptosporidium spp antigen by ELISA method in stool specimens obtained from patients with diarrhoea. Parasitol Res 2011; 108(2): 395-7.

[25] Bialek R, Binder N, Dietz K, Joachim A, Knobloch J, Zelek UE. Comparison of fluorescence antigen and PCR assays to detect Cryptosporidium parvum in faecal specimens. Dignos Microbiol Infect Dis 2002; 43: 283-8.

[26] Ungar BLP. Cryptosporidium. In: Mandell, GL., Bennett, JE. and Dohn, R, Eds. Mandell, Douglas and Bennett's principle and practice of infectious diseases. $5^{\text {th }}$ Ed. Philadelphia, Pa: Churchill Livingstone. 2000; pp. 2903-15.

[27] Ikeh EI, Obadofin M, Brindeiro B, et al. Intestinal parasitism in rural and urban area of Northcentral Nigeria: An update. The Internet J Microbiol 2006; 2: 1-12.

[28] Ikechukwu D, Benjamin N, Uchechukwu C. Cryptosporidiosis in Imo State, Nigeria. J Rural Trop Publ Hlth 2011; 10: 106-10. 
[29] Assefa S, Erko B, Medhin G, Assefa Z, Shimelis T. Intestinal parasitic infections in relation to HIV/AIDS status, diarrhoea and CD4 T-cell count. BMC Infect Dis 2009; 9: 155. doi: $10.1186 / 1471-2334-9-155$

[30] Egberongbe HO, Agbolade OM, Adesetan TO, Mabekoje OO, Olugbode AM. Cryptosporidiosis among children in relation to toilet facilities and water sources in Ijebu and Remo area, South Western Nigeria. J Med Medical Scien 2010; 1(10): 485-9.

[31] Hunter PR, Hughes S, Woodhouse S, et al. Sporadic cryptosporidiosis case control study with genotyping. Emerg Infect Dis 2004; 10(7): 1241-9.

[32] Morgan U, Weber R, Xiao L, Sulaiman I, Thompson RC, Ndiritu W. Molecular characterization of Cryptosporidium isolates obtained from Human immunodeficiency virus - infected individuals living in Switzerland, Kenya and United States. J Clin Microbiol 2000; 38: 110-3.
[33] Aragon TJ, Novothy S, Enanoria W, Vulgia DJ, Khalakdina A, Katz MH). Endemic cryptosporidiosis and exposure to municipal tap water in person with acquired immunodeficiency syndrome: a case-control study. BioMed Central Publc Hlth 2003; 3:2. doi:10.1186/1471-2458-3-2

[34] Banwat EB, Egah DZ, Onile BA, Angyo RA, Audu ES. Prevalence of Cryptosporidium infection among undernourished children in Jos, Central Nigeria. Nig Postgrad Med J 2003; 10(2): 84-97.

[35] Ajjampur SS, Sankaran P, Kang G. Cryptosporidium species in HIV-infected individual in India: an overview. Natl Med J India 2008; 21(4): 178-84.

[36] Gupta S, Narong S, Nanavata V, Singh S. Chronic diarrhoea in HIV: prevalence of coccidian parasites. Ind J Med Microbiol 2008; 26(2): $172-5$.

(C) Aminu et al.; Licensee Bentham Open.

This is an open access article licensed under the terms of the Creative Commons Attribution Non-Commercial License (http://creativecommons.org/licenses/bync/3.0/), which permits unrestricted, non-commercial use, distribution and reproduction in any medium, provided the work is properly cited. 